Louisiana State University

LSU Digital Commons

$5-1-2008$

\title{
Stand structure and dynamics of sand pine differ between the Florida panhandle and peninsula
}

\author{
Paul B. Drewa \\ Case Western Reserve University \\ William J. Platt \\ Louisiana State University \\ Charles Kwit \\ Miami University \\ Thomas W. Doyle \\ National Wetlands Research Center
}

Follow this and additional works at: https://digitalcommons.Isu.edu/biosci_pubs

\section{Recommended Citation}

Drewa, P., Platt, W., Kwit, C., \& Doyle, T. (2008). Stand structure and dynamics of sand pine differ between the Florida panhandle and peninsula. Plant Ecology, 196 (1), 15-25. https://doi.org/10.1007/ s11258-007-9333-6 


\title{
Stand structure and dynamics of sand pine differ between the Florida panhandle and peninsula
}

\author{
Paul B. Drewa - William J. Platt · Charles Kwit • \\ Thomas W. Doyle
}

Received: 27 March 2006/Accepted: 19 June 2007/Published online: 11 July 2007

(C) Springer Science+Business Media B.V. 2007

\begin{abstract}
Size and age structures of stand populations of numerous tree species exhibit uneven or reverse J-distributions that can persist after noncatastrophic disturbance, especially windstorms. Among disjunct populations of conspecific trees, alternative distributions are also possible and may be attributed to more localized variation in disturbance. Regional differences in structure and demography among disjunct populations of sand pine (Pinus clausa (Chapm. ex Engelm.) Vasey ex Sarg.) in the Florida panhandle and peninsula may result from variation in hurricane regimes associated with each of these populations. We measured size, age, and growth rates of trees from panhandle and peninsula populations and then compiled size and age class distributions. We also characterized hurricanes in
\end{abstract}

P. B. Drewa $(\bowtie)$

Department of Biology, Case Western Reserve

University, Cleveland, $\mathrm{OH}$ 44106, USA

e-mail: paul.drewa@case.edu

\section{W. J. Platt}

Department of Biological Sciences, Louisiana State University, Baton Rouge, LA 70803, USA

C. Kwit

Department of Botany, Miami University, Oxford, OH 45056, USA

T. W. Doyle

US Geological Survey, National Wetlands Research

Center, Lafayette, LA 70506, USA both regions over the past century. Size and age structures of panhandle populations were unevenly distributed and exhibited continuous recruitment; peninsula populations were evenly sized and aged and exhibited only periodic recruitment. Since hurricane regimes were similar between regions, historical fire regimes may have been responsible for regional differences in structure of sand pine populations. We hypothesize that fires were locally nonexistent in coastal panhandle populations, while periodic high intensity fires occurred in peninsula populations over the past century. Such differences in local fire regimes could have resulted in the absence of hurricane effects in the peninsula. Increased intensity of hurricanes in the panhandle and current fire suppression patterns in the peninsula may shift characteristics of sand pine stands in both regions.

Keywords Disturbance regimes $\cdot$ Hurricane $\cdot$ Pinus clausa $\cdot$ Size and age distribution $\cdot$ Windstorms

\section{Introduction}

Unevenly distributed size and age structures that approximate negative exponential or "reverse-J" distributions are exhibited by numerous tree populations at local, stand scales (Rubin et al. 2006). Further, this distribution type is strikingly similar among disjunct populations of hardwood species that are resident to both cool- and warm-temperate forests 
of North America, variously dominated by Acer, Fagus, Liquidambar, and Quercus (Muller 1982; Poulson and Platt 1996; Quigley and Platt 1996; Duchesne et al. 2005). Uneven size and age distributions have also been reported for trees characteristic of tropical forests and hammocks (Slater et al. 1995; Killeen et al. 1998; McLaren et al. 2005) as well as conifer forests (Diaz et al. 2000; Wang et al. 2004) and pine savannas worldwide (Gilliam and Platt 1999; Platt et al. 2000).

Such reverse-J distributions of size and age structures can persist following disturbances that do not completely kill all trees and thus are noncatastrophic. This is especially the case in ecosystems characterized by periodic wind disturbance, including hurricanes and tropical storms, where mortality is often negligible (<20\%; Gilliam et al. 2006) and positively associated with tree size and age (Batista et al.1998; Platt et al. 2000; Ida 2000). On the other hand, there have been repeated suggestions that some disjunct populations of conspecific trees exhibit differences in size distributions and age structures at regional scales (Schmelz and Lindsey 1965; Goff and West 1975; Brown et al. 2003; Ryniker et al. 2006; Westphal et al. 2006). Alternative stand structures (e.g., rotated sigmoid, unimodal), which also are associated with ecosystems characterized by windstorms, may result from localized variation in disturbance (Westphal et al. 2006).

Disjunct populations of sand pine (Pinus clausa (Chapm. ex Engelm.) Vasey ex Sarg.) occur in eastern coastal Alabama-panhandle Florida and over much of the Florida peninsula (Myers 1990). Structural differences in stand dynamics between these two regions have been suggested to be associated with disturbances (Parker et al. 2001a). The size and age structures of the panhandle populations studied by Parker et al. (2001a) were unevenly distributed, while those in the peninsula populations studied tended to be unimodal or evenly distributed. Nonetheless, disjunct populations of sand pine have not been examined across the range of this species; thus, regional comparisons have yet to be rigorously evaluated. Additionally, the extent to which localized variation in hurricane regimes might be associated with stand structure and dynamics of disjunct sand pine populations has not been explored.

We examine stand structure and dynamics for disjunct populations of sand pine across most of the range of this species. In addition, we compile characteristics of hurricane regimes associated with each population studied. Two questions are addressed: (1) Are size and age structures of sand pine populations consistently more different between the Florida panhandle and peninsula than within these two regions? (2) Are localized characteristics of hurricanes different among disjunct populations, both within each region and between the panhandle and peninsula of Florida? We answer these questions by comparing size class distributions and stem densities of stands across the Florida panhandle and peninsula. We test whether size class distributions reflect age structures within and between these regions via comparisons of age-size relationships and age class distributions determined from dendrochronological data. Hurricane frequency and intensity are also characterized for each population. We then use results of our study to discuss the nature of differences among the disjunct populations and consider the possibility that large differences in disturbance regimes might explain local and regional differences in stand structure and dynamics of sand pine.

\section{Methods}

Study sites

We studied five sites in the Florida panhandle and seven sites in the peninsula, all of which are characterized by an overstory of mostly sand pine. Sand pine populations have been repeatedly hypothesized to differ between the two regions, resulting in descriptions of different varieties ( $P$. clausa var. immuginata and P. clausa var. clausa, respectively; Little and Dorman 1952; Ward 1963). However, no consistent differences in morphology, including cone serotiny, have been identified (Myers 1990), and only small differences in genetic structure have been noted (Parker and Hamrick 1996).

Understory vegetation in the panhandle is sparsely distributed with oaks (Quercus geminata Small, Quercus myrtifolia Willd., Quercus chapmannii Sarg., Quercus arkansana Sarg.), scrub hickories (Carya alba (L.) Nutt. ex Ell.), and southern magnolia (Magnolia grandiflora L.; Myers 1990; Outcalt 1997) as well as lichens (Cladonia spp.) in the ground cover (Buckley and Hendrickson 1988). Five pan- 
handle sites were examined along the Florida Gulf Coast: (1) Big Lagoon State Park, (2) Fred Gannon Rocky Bayou State Park, (3) St. Andrews State Park, (4) St. Joseph Peninsula State Park, and (5) Bald Point State Park (Table 1). These sites are hereafter referred to as Big Lagoon, Rocky Bayou, St. Andrews, St. Joseph, and Bald Point, respectively.

Sand pine stands in the Florida peninsula are often referred to as "scrub" where the understory is dense and comprised of shrubs, including oaks, rosemary (Ceratiola ericoides Michx.), tree lyonia (Lyonia ferruginea (Walt.) Nutt.), palmettos (Sabal etonia Swingle ex Nash, Serenoa repens (Bartr.) Small), and ground blueberry (Vaccinium myrsinites Lam.; Laessle 1958; Abrahamson 1984). There are endemic forbs, especially along Lake Wales Ridge (Abrahamson et al. 1984; Christman and Judd 1990). Our seven peninsula sites occur inland and included: (1) Mike Roess Gold Head Branch State Park, (2) Big Scrub Recreational Area in the Ocala National Forest, (3) Rock Springs Run State Reserve, (4) Wekiwa Springs State Park, (5) Saddleblanket Lakes Preserve, (6) Arbuckle Tract in the Lake Wales Ridge State Forest, and (7) Highlands Hammock State Park (Table 1). We refer to these sites hereafter as Gold Head Branch, Big Scrub, Rock Springs Run, Wekiwa Springs, Saddleblanket, Arbuckle Tract, and Highlands Hammock, respectively. Nomenclature follows Clewell (1985) and Godfrey (1988).
All our study sites in the Florida panhandle and peninsula were selected because they were accessible and are protected preserves where the land use history is more or less known.

Data collection

In 1992, we randomly established sampling plots within natural sand pine stands at each site (Table 1). While 46 plots were established throughout the Florida panhandle, 26 plots were used in the peninsula. The number of established plots within any given site ranged from 3 to 10, depending on sizes of stands. Each plot was $20 \times 20-\mathrm{m}$. However, two of the 10 plots at Big Lagoon were $500-750 \mathrm{~m}^{2}$, while one of the 10 established plots at Rocky Bayou and St. Andrews was $300-500 \mathrm{~m}^{2}$. Diameter at breast height (dbh) was measured for sand pines $\geq 1.5 \mathrm{~m}$ tall and $\geq 2 \mathrm{~cm}$ dbh in each plot. Also, we randomly selected trees within $5 \mathrm{~cm}$ size classes and cored them using increment borers. At each site, 14-61 trees were cored; two cores were extracted from opposite sides of each tree. Lab preparation of core samples included air-drying and gluing of cores into grooved mounting sticks. We finely sanded each sample mount to achieve a polished surface. Polished samples were dated by assigning calendar years to growth rings based on ring order and size pattern. Drought years generally produced narrow rings, and wet years

Table 1 Location, number of plots, and total area sampled $\left(\mathrm{m}^{2}\right)$ for each of 12 sites in the Florida panhandle and peninsula

\begin{tabular}{|c|c|c|c|c|}
\hline Site & County & Latitude, longitude & $\begin{array}{l}\text { Number } \\
\text { of plots }\end{array}$ & $\begin{array}{l}\text { Total area } \\
\text { sampled/site }\left(\mathrm{m}^{2}\right)\end{array}$ \\
\hline \multicolumn{5}{|l|}{ Panhandle } \\
\hline Big Lagoon & Escambia & $30^{\circ} 19^{\prime} \mathrm{N}, 87^{\circ} 25^{\prime} \mathrm{W}$ & 10 & 5350 \\
\hline Rocky Bayou & Okaloosa & $30^{\circ} 29^{\prime} \mathrm{N}, 86^{\circ} 26^{\prime} \mathrm{W}$ & 10 & 4100 \\
\hline St. Andrews & Bay & $30^{\circ} 08^{\prime} \mathrm{N}, 85^{\circ} 44^{\prime} \mathrm{W}$ & 10 & 3900 \\
\hline St. Joseph & Gulf & $29^{\circ} 48^{\prime} \mathrm{N}, 85^{\circ} 25^{\prime} \mathrm{W}$ & 8 & 3200 \\
\hline Bald Point & Franklin & $29^{\circ} 56^{\prime} \mathrm{N}, 84^{\mathrm{o}} 22^{\prime} \mathrm{W}$ & 8 & 3200 \\
\hline \multicolumn{5}{|l|}{ Peninsula } \\
\hline Gold Head Branch & Clay & $29^{\circ} 51^{\prime} \mathrm{N}, 81^{\circ} 57^{\prime} \mathrm{W}$ & 3 & 1200 \\
\hline Big Scrub & Marion & $29^{\circ} 00^{\prime} \mathrm{N}, 81^{\circ} 47^{\prime} \mathrm{W}$ & 7 & 2800 \\
\hline Rock Springs Run & Orange & $28^{\circ} 46^{\prime} \mathrm{N}, 81^{\circ} 27^{\prime} \mathrm{W}$ & 3 & 1200 \\
\hline Wekiwa Springs & Orange & $28^{\circ} 43^{\prime} \mathrm{N}, 81^{\circ} 29^{\prime} \mathrm{W}$ & 4 & 1600 \\
\hline Saddleblanket & Polk & $27^{\circ} 50^{\prime} \mathrm{N}, 81^{\circ} 41^{\prime} \mathrm{W}$ & 3 & 1200 \\
\hline Arbuckle Tract & Polk & $27^{\circ} 42^{\prime} \mathrm{N}, 81^{\circ} 27^{\prime} \mathrm{W}$ & 3 & 1200 \\
\hline Highlands Hammock & Highland & $27^{\circ} 29^{\prime} \mathrm{N}, 81^{\circ} 31^{\prime} \mathrm{W}$ & 3 & 1200 \\
\hline
\end{tabular}


produced wide rings in patterns concomitant with regional climate history. We determined tree age using the earliest ring date at the pith. Samples without pith were given a projected age based on ring angle and growth rate at or near the tree center from the innermost ring date.

\section{Statistical analyses}

For each of the 12 sites, we constructed size class distributions using all sand pine trees in our plots. We began to describe these distributions by comparing them individually to a normal distribution using a Kolmogorov-Smirnov goodness of fit test, since it has been suggested that some size class distributions of sand pine, particularly in the Florida peninsula, appear normally distributed (Parker et al. 2001a). We also calculated a coefficient of variation and a skewness estimate for each site's size class distribution (Sokal and Rohlf 1995). ANOVA was then used to examine if these coefficients of variation and skewness estimates were different between the panhandle and peninsula sites (two separate analyses).

Three separate ANOVA's were also performed to examine differences in stand density between the Florida panhandle and peninsula as well as among sites within each region. Significant differences among sites within each region were further explored using Tukey-Kramer pairwise comparisons. We analyzed density data that included (1) trees $\geq 2 \mathrm{~cm} \mathrm{dbh}$, (2) trees $2-20 \mathrm{~cm} \mathrm{dbh}$, and (3) trees $2-10 \mathrm{~cm} \mathrm{dbh}$. The latter two tests helped address if there were regional differences in sand pine recruitment. Each of the three analyses was conducted as a completely randomized design, but with nested sampling (plots within sites). Differences between regions and among sites within each of the panhandle and peninsula were examined using sites and plots as sampling units, respectively.

Similar to Gilliam and Platt (1999) and Platt et al. (2000), we used simple linear regression to examine relationships involving tree size versus age of cored trees for each of the 12 study sites. ANOVA was then used to compare growth rates (regression slopes), average size, and average age between the panhandle and peninsula using sites as sampling units (three separate analyses). These linear relationships enabled us to generate predicted age class distributions for each of the 12 sites. These distributions were subsequently analyzed in the same way as our size class distributions employing a Kolmogorov-Smirnov goodness of fit test, calculating coefficients of variation and skewness estimates, and using ANOVA.

We compared the number of hurricanes (defined here as windstorms $>112 \mathrm{~km} / \mathrm{h}$ ) and the number of 10 min intervals with winds $>112 \mathrm{~km} / \mathrm{h}$ in the Florida panhandle and peninsula during a 109 year period using ANOVA where the 12 sites served as sampling units (two separate analyses). We determined the number of hurricanes for each of the 12 sites, using historic tracking and meteorological data of dated North Atlantic tropical storms and hurricanes from 1886 through 1994. At each site during this 109 year period, the number of 10-min intervals with winds $>112 \mathrm{~km} / \mathrm{h}$ (this measure weights the number of hurricanes by storm intensity) was constructed using HURASIM, an empirical model that recreates the spatial structure of past hurricanes based on a tangential wind function, inflow angle offset, forward speed, and radius of maximum winds (Doyle et al. 2002).

Kolmogorov-Smirnov goodness of fit tests and calculations of coefficients of variation and skewness estimates were conducted in SAS (SAS Institute Inc. 2001) using Proc Univariate. ANOVA's and TukeyKramer pairwise comparisons and regressions were also conducted in SAS using Proc Mixed and Proc Reg, respectively. ANOVA's were performed using natural $\log$ transformed data to comply with model assumptions. For all analyses, $\alpha=0.05$.

\section{Results}

Size class distributions

Size class distributions of sand pine were structurally different between the Florida panhandle and peninsula. In each panhandle site, trees were unevenly and non-normally distributed (Kolmogorov-Smirnov $P<0.015$; Table 2) among size classes (Fig. 1a-e). In contrast, trees were evenly and normally distributed (Kolmogorov-Smirnov $P>0.103$ ) in each of the seven peninsula sites (Fig. 1f-l).

Compared to size class distributions in the peninsula, those in the panhandle yielded larger coefficients of variation $(P=0.002)$ and were skewed differently $(P=0.004$; Table 2$)$. In each panhandle 
Table 2 Kolmogorov-Smirnov goodness of fit test $P$-values, coefficients of variation, and skewness estimates of size class distributions for sand pine trees that were measured for dbh in each of 12 study sites of the Florida panhandle and peninsula

\begin{tabular}{llcr}
\hline Site & $\begin{array}{l}\text { Kolmogorov- } \\
\text { Smirnov } \\
P \text {-values }\end{array}$ & $\begin{array}{l}\text { Coefficient } \\
\text { of variation }\end{array}$ & $\begin{array}{l}\text { Skew- } \\
\text { ness }\end{array}$ \\
\hline Panhandle & & & \\
$\quad$ Big Lagoon & 0.015 & 54.84 & 0.07 \\
Rocky Bayou & 0.010 & 114.43 & 1.32 \\
St. Andrew & 0.010 & 56.03 & 0.16 \\
St. Joseph & 0.010 & 66.66 & 0.69 \\
Bald Point & 0.010 & 58.51 & 0.19 \\
Peninsula & & & \\
Gold Head Branch & 0.150 & 35.88 & -0.54 \\
Big Scrub & 0.103 & 38.09 & 0 \\
Rock Springs Run & 0.147 & 37.98 & -0.44 \\
Wekiwa Springs & 0.150 & 36.06 & -0.25 \\
Saddleblanket & 0.150 & 39.23 & -0.46 \\
Arbuckle Tract & 0.109 & 47.62 & -0.15 \\
Highlands Hammock & 0.150 & 45.05 & -0.22 \\
\hline
\end{tabular}

$P$-values $<0.05$ indicate a rejection of the null hypothesis of a normal size class distribution

$P$-values, coefficients of variation, and skewness estimates for predicted age class distributions were exactly the same as those for our size class distributions

site, tree diameters were highly variable relative to the mean (CV ranged from 55 to 114), and were skewed toward larger size classes (values ranged from 0.07 to 1.32). Large-sized trees (e.g., $40-60 \mathrm{~cm}$ dbh) were present in both regions. However, distributions in the peninsula yielded smaller coefficients of variation ( $\mathrm{CV}$ ranged from 36 to 48 ) and were either not skewed or skewed toward under-represented smaller size classes (values ranged from -0.54 to 0 ).

Stand densities of trees $\geq 2 \mathrm{~cm}$ dbh, between 2 and $20 \mathrm{~cm} \mathrm{dbh}$, and $2-10 \mathrm{~cm}$ dbh were greater in the panhandle (1033.2 trees/ha \pm 93.3 SE, 778.9 trees/ ha \pm 95.0 , and 488.0 trees/ha \pm 92.7 , respectively) than in the peninsula (393.3 trees/ha $\pm 29.0 \mathrm{SE}, 136.0$ trees/ ha \pm 16.0 , and 39.8 trees/ha \pm 6.6 , respectively; $P<0.001$ for each comparison; Table 3). Variation in stem densities among sites within regions was also detected $(P<0.001)$. In the panhandle, low-stem densities at Big Lagoon for all three size classes set this site apart from sites with higher-stem densities, such as St. Joseph and especially Rocky Bayou (Table 3). In the peninsula, low stem densities of smaller stems (210 and $2-20 \mathrm{~cm} \mathrm{dbh}$ ) at Saddleblanket and Wekiwa Springs set these sites apart from others.

Size-age relationships

There were positive linear relationships involving tree size as a function of age in the Florida panhandle and almost all sites in the peninsula (Table 4). In the panhandle, these relationships yielded slopes that were different from zero $(P<0.001)$. In the peninsula, slopes were also different from zero $(P<0.001)$ at Big Scrub, Rock Springs Run, Saddleblanket, Arbuckle Tract, Highlands Hammock, Wekiwa Springs $(P=0.047)$, but not Gold Head Branch $(P=0.302)$. Moreover, the growth rate of sand pine (regression slopes) was almost three times greater in the peninsula than in the panhandle $(P=0.014)$. This resulted in predicted age class distributions that reflected the size class distributions (Table 2), with trees attaining larger sizes at younger ages in the peninsula (Fig. 1).

Compared to the panhandle, trees were generally larger, but younger in the peninsula (Table 4). Trees averaged $18.0 \mathrm{~cm}$ dbh across the panhandle sites, but $24.0 \mathrm{~cm}$ dbh across the peninsula sites $(P=0.014)$. Additionally, sand pine trees were 34.4 years old on average across peninsula sites, but almost 60 years old in the panhandle $(P=0.013)$. Tree age ranged from 9 to 146 years in the panhandle and 8-76 years in the peninsula.

\section{Hurricanes}

The number of hurricanes crossing the coast from 1886 through 1994 was similar between the panhandle (14.2 hurricanes $\pm 1.8 \mathrm{SE}$ ) and peninsula (17.7 hurricanes $\pm 2.2 \mathrm{SE} ; P=0.273$; Table 5). The number of 10 -min intervals with winds $>112 \mathrm{~km} / \mathrm{h}$ was also equivalent between regions $(P=0.321)$, averaging $207.8( \pm 29.6 \mathrm{SE})$ in the panhandle and $244.4( \pm 20.9$ $\mathrm{SE})$ in the peninsula.

\section{Discussion}

Despite the occurrence of similar hurricane frequencies and intensities in the Florida panhandle and peninsula, size and age structures were different 
Fig. 1 Size and predicted age class distributions (bar and line graphs, respectively) of five sites in the Florida panhandle ((a) Big Lagoon, (b) Rocky Bayou, (c) St. Andrews, (d) St. Joseph, and (e) Bald Point) and seven sites in the peninsula ((f) Gold Head Branch, (g) Big Scrub,

(h) Rock Springs Run,

(i) Wekiwa Springs,

(j) Saddleblanket,

(k) Arbuckle Tract, and

(l) Highlands Hammock)

\section{Age Class (yr)}

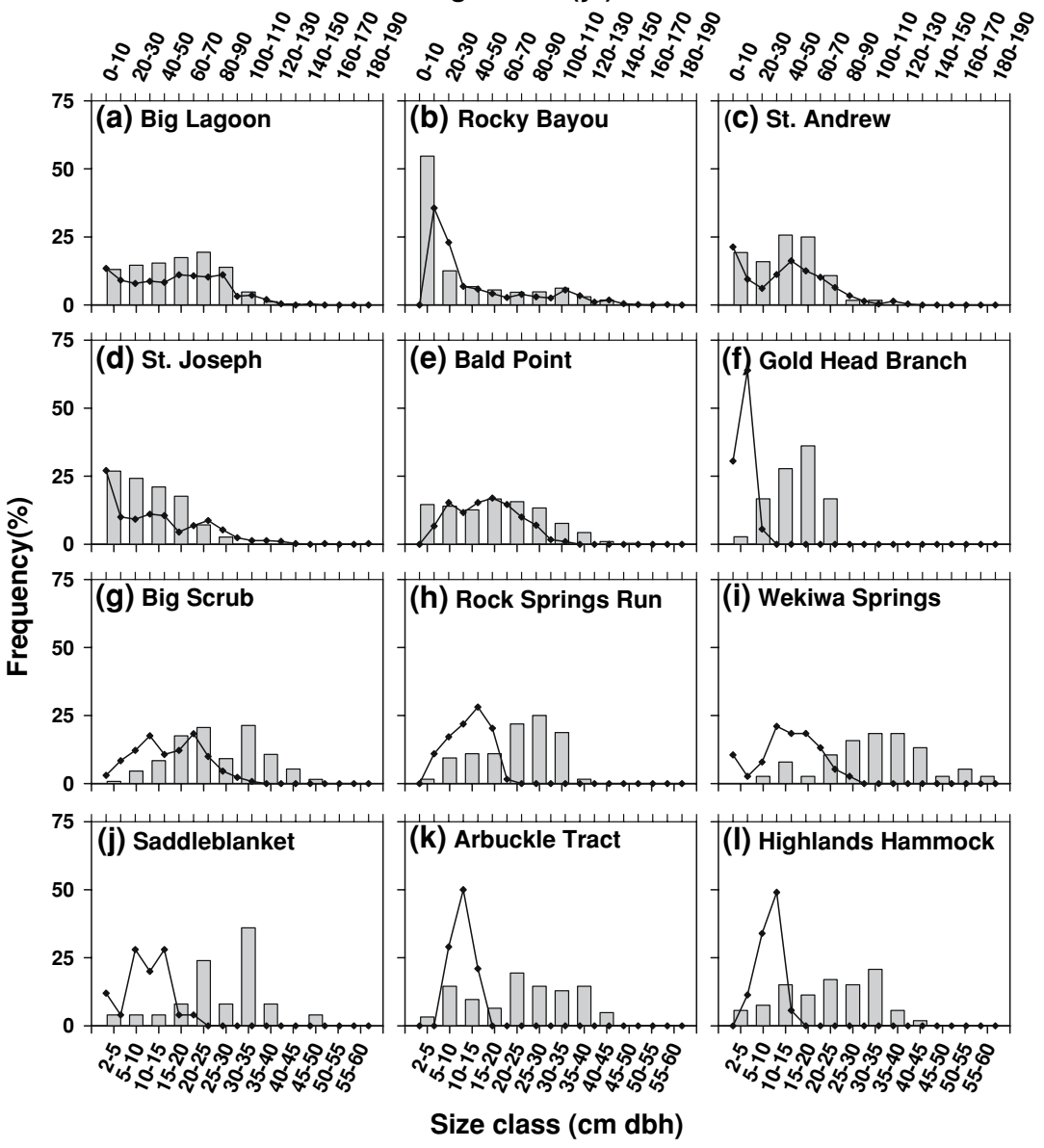

between regions. Moreover, we propose that standclearing fires over the past century, and not hurricanes, account for even size and age class distributions in the Florida peninsula. Here, hurricanes have undoubtedly caused mortality, especially of large, reproductively mature trees, as occurs in other pine species (cf. Platt and Rathbun 1993; Platt et al. 2000). Additionally, hurricanes have generated openings in peninsula sand pine stands. Such openings usually result in recruitment and release of advance recruits in other coniferous forests (Taylor and Halpern 1991; Kneeshaw and Burton 1997). However, if similar events occur in the Florida peninsula such that sand pine populations can develop uneven size and age class distributions, they are likely removed by stand replacing fires, leaving few survivors (Laessle 1942, 1958). Intense fires, which historically occurred at frequencies well within the lifetime of a sand pine tree (i.e., 10-100 years;
Mulvania 1931; Cooper 1959) and are currently utilized in managed areas (Greenberg 2003), should nullify hurricane effects, resulting in size and age structures that are more evenly distributed than expected in the absence of fires. Thus, we hypothesize that stand-clearing fires may have interacted antagonistically with hurricanes over much of the peninsula.

The panhandle sites we studied appear to have had no large stand-clearing fires over the past century, which may explain why sand pine trees were as old as 146 years. The unevenly distributed size and age structures of our sand pine populations resemble those of other stands in the Florida panhandle which are also described as either lacking fire or as having fire predate the oldest trees (Conway et al. 1997; Parker et al. 2001b). The structure of these sand pine populations has been proposed to be influenced primarily by hurricanes, and stem growth rates have been shown to increase following hurricanes (Parker 
Table 3 Mean $( \pm$ SE) stand density (number of trees/ha) of trees $\geq 2 \mathrm{~cm}, 2-20 \mathrm{~cm}$, and $2-10 \mathrm{~cm}$ dbh for 12 study sites in the Florida panhandle and peninsula

\begin{tabular}{|c|c|c|c|c|c|c|}
\hline \multirow[t]{3}{*}{ Site } & \multicolumn{6}{|c|}{ Stand density (number of trees/ha) } \\
\hline & \multicolumn{2}{|c|}{$\geq 2 \mathrm{~cm} \mathrm{dbh}$} & \multicolumn{2}{|c|}{$2-20 \mathrm{~cm} \mathrm{dbh}$} & \multicolumn{2}{|c|}{$2-10 \mathrm{~cm} \mathrm{dbh}$} \\
\hline & Mean & SE & Mean & SE & Mean & SE \\
\hline \multicolumn{7}{|l|}{ Panhandle } \\
\hline Big Lagoon & $632.5^{\mathrm{a}}$ & 45.0 & $299.0^{\mathrm{a}}$ & 42.6 & $130.0^{\mathrm{a}}$ & 31.1 \\
\hline Rocky Bayou & $1677.5^{\mathrm{c}}$ & 308.9 & $1327.5^{\mathrm{b}}$ & 322.5 & $1125.5^{\mathrm{b}}$ & 317.8 \\
\hline St. Andrews & $740.0^{\mathrm{ab}}$ & 70.4 & $669.2^{\mathrm{ab}}$ & 96.1 & $289.2^{\mathrm{ab}}$ & 103.2 \\
\hline St. Joseph & $1187.5^{\mathrm{b}}$ & 163.7 & $1065.6^{\mathrm{b}}$ & 156.5 & $606.3^{\mathrm{ab}}$ & 152.6 \\
\hline Bald Point & $940.6^{\mathrm{ab}}$ & 88.4 & $543.8^{\mathrm{ab}}$ & 85.1 & $268.8^{\mathrm{ab}}$ & 47.9 \\
\hline Overall & 1033.2 & 93.3 & 778.9 & 95.0 & 488.0 & 92.7 \\
\hline \multicolumn{7}{|l|}{ Peninsula } \\
\hline Gold Head Branch & 300.0 & 50.0 & $228.3^{\mathrm{c}}$ & 17.4 & $53.3^{\mathrm{bc}}$ & 3.3 \\
\hline Big Scrub & 467.9 & 52.8 & $146.4^{\mathrm{c}}$ & 20.0 & $25.0^{\mathrm{abc}}$ & 7.7 \\
\hline Rock Springs Run & 533.3 & 50.7 & $175.0^{\mathrm{b}}$ & 28.9 & $58.3^{\mathrm{bc}}$ & 8.3 \\
\hline Wekiwa Springs & 237.5 & 23.9 & $31.3^{\mathrm{ab}}$ & 6.3 & $6.3^{\mathrm{a}}$ & 6.3 \\
\hline Saddleblanket & 208.3 & 8.3 & $41.7^{\mathrm{a}}$ & 22.0 & $16.7^{\mathrm{ab}}$ & 16.7 \\
\hline Arbuckle Tract & 516.7 & 44.1 & $175.0^{\mathrm{b}}$ & 28.9 & $91.7^{\mathrm{c}}$ & 16.7 \\
\hline Highlands Hammock & 441.7 & 30.0 & $175.0^{\mathrm{b}}$ & 62.9 & $58.3^{\mathrm{bc}}$ & 22.0 \\
\hline Overall & 393.3 & 29.0 & 136.0 & 16.0 & 39.8 & 6.6 \\
\hline
\end{tabular}

Included is the overall mean $( \pm \mathrm{SE})$ of stand density for each of the three size categories by region

Stand densities for all three size classes were greater in the panhandle than in the peninsula $(P<0.001)$

Differences among sites within a region are indicated by different superscripted letters (Tukey-Kramer $P<0.05$ )

et al. 2001a). However, neither our data nor those of Parker et al. (2001a) support the hypothesis that episodes of increased seedling establishment occur after hurricanes. Instead, almost continual recruitment in our sites may be tied mostly to (1) opening of serotinous cones in the absence of fire and (2) overstory tree mortality via treefall gaps caused by hurricanes and tropical storms, as well as other causes (e.g., lightning strikes). Variation in local and widespread disturbances likely infuses temporal and spatial variability in recruitment as observed in piñon pine-oak forests of Mexico (Díaz et al. 2000) and south Florida pine savannas (Platt et al. 2000); nonetheless, our panhandle populations exhibit markedly similar structures.

Historically, differences in fire regimes could have resulted in different interactive effects of fires and hurricanes on panhandle and peninsula sand pine populations. Sand pine stands in both regions were once situated in a larger, contiguous pyrogenic matrix. Coastal panhandle stands adjoined swales containing pyrogenic herbaceous vegetation and slash pine (Pinus elliottii var. elliottii Engelm.); historic fire return intervals in these adjacent areas averaged more than twice per decade when humans were not extracting resins (Huffman et al. 2004). Peninsula stands adjoined large savannas containing longleaf pine (P. palustris Mill.) or slash pine (Myers 1990) that historically also burned more than twice per decade (Platt 1999). Low productivity in coastal panhandle stands and slower growth of pines evident on old coastal dunes where our study sites occur may have reduced the likelihood of fire spread into sand pine stands. Regardless, the low probability of fire in panhandle sand pine stands would have resulted in the preponderance of uneven size and age structures across the region. In a historically less naturally fragmented and more productive peninsula landscape, propagules from nearby, recently burned stands could have established in hurricane-influenced stands or cones may have opened without fire. Nonetheless, subsequent stand-clearing fires should 
Table 4 Regression equations describing linear relationships between tree size (y) versus tree age ( $\mathrm{x}$ ) for cored trees (N) at study sites in the Florida panhandle and peninsula

\begin{tabular}{|c|c|c|c|c|c|c|c|}
\hline Site & $\begin{array}{l}\text { Regression equation } \\
(\mathrm{y}=\mathrm{ax}+\mathrm{b})\end{array}$ & $\mathrm{N}$ & Slope SE & $r^{2}$ & $\begin{array}{l}\text { Mean size } \\
(\mathrm{cm} \text { dbh })\end{array}$ & $\begin{array}{l}\text { Mean age } \\
\text { (years) }\end{array}$ & $\begin{array}{l}\text { Range in } \\
\text { age (years) }\end{array}$ \\
\hline \multicolumn{8}{|l|}{ Panhandle } \\
\hline Big Lagoon & $y=0.28 x+2.44$ & 51 & 0.05 & 0.40 & 17.9 & 55.3 & $13-146$ \\
\hline Rocky Bayou & $y=0.33 x-4.16$ & 61 & 0.03 & 0.65 & 20.9 & 76.0 & $17-133$ \\
\hline St. Andrews & $y=0.24 x+3.30$ & 42 & 0.07 & 0.25 & 13.6 & 43.2 & $11-89$ \\
\hline St. Joseph & $y=0.20 x+3.07$ & 45 & 0.03 & 0.53 & 15.4 & 61.6 & $9-132$ \\
\hline Bald Point & $y=0.49 x-7.21$ & 47 & 0.05 & 0.72 & 22.0 & 59.3 & $17-101$ \\
\hline Overall & $0.31 \pm 0.05$ & & & & $18.0 \pm 1.6$ & $59.1 \pm 5.3$ & \\
\hline \multicolumn{8}{|l|}{ Peninsula } \\
\hline Gold Head Branch & $y=0.91 x+3.18$ & 14 & 0.84 & 0.09 & 13.6 & 11.4 & $8-15$ \\
\hline Big Scrub & $y=0.43 x+4.88$ & 41 & 0.84 & 0.37 & 27.0 & 51.9 & $15-76$ \\
\hline Rock Springs Run & $y=0.67 x-3.95$ & 17 & 0.16 & 0.54 & 22.9 & 39.6 & $17-50$ \\
\hline Wekiwa Springs & $y=0.60 x+6.53$ & 21 & 0.28 & 0.19 & 32.1 & 42.7 & $23-67$ \\
\hline Saddleblanket & $y=0.68 x+5.19$ & 16 & 0.15 & 0.59 & 25.5 & 30.1 & $10-62$ \\
\hline Arbuckle Tract & $y=1.56 x-29.74$ & 20 & 0.22 & 0.74 & 22.2 & 33.3 & $21-42$ \\
\hline $\begin{array}{l}\text { Highlands } \\
\text { Hammock }\end{array}$ & $y=1.36 x-18.95$ & 18 & 0.37 & 0.47 & 24.4 & 31.7 & $16-50$ \\
\hline Overall & $0.89 \pm 0.16$ & & & & $24.0 \pm 2.1$ & $34.4 \pm 4.8$ & \\
\hline
\end{tabular}

Standard errors of slopes (Slope SE), amount of variation explained by regression equations $\left(\mathrm{r}^{2}\right)$, as well as mean size (cm dbh), mean age (years), and range in age (years) for cored trees for each study site are provided. Also included are the mean $( \pm \mathrm{SE})$ regression slope and the overall mean $( \pm \mathrm{SE})$ size and age by region: $\mathrm{a}=$ slope, $\mathrm{b}=\mathrm{y}$-intercept

have resulted in an antagonistic outcome, in which the effects of any hurricane would have been nullified by subsequent fires.

Different size and age structures between the Florida panhandle and peninsula are likely not attributed to regional differences in climatic and edaphic characteristics. With the exception of slightly more rain during spring months in the Florida peninsula, rainfall as well as temperature patterns are very similar throughout the range of sand pine (Parker et al. 2001b). In addition, differences in numerous soil characteristics are negligible between regions (Evans et al. 1996). For example, differences in sand and clay content of white coastal panhandle soils and yellow inland peninsula soils (corresponding to the colors of soils in our sites) are $<4 \%$, while regional differences in $\mathrm{pH}$ and nutrients $(\mathrm{Al}, \mathrm{Ca}, \mathrm{Mg}$ ) are only $<0.5$ units and $<100$ ppm, respectively. These small differences, and the lack of differences found in other soil properties, led Evans et al. (1996) to agree with Kalisz and Stone's (1984) assessment of the general lack of soil differences across the range of sand pine.
Light regimes, especially at highly localized scales, are also not appreciably different between the Florida panhandle and peninsula based on two pieces of evidence provided by Conway et al. (1997). First, shrub foliage height densities and highly localized surface light levels in sand pine stands are equivalent between regions. Second, sand pine regeneration was associated with higher surface light levels and lower shrub foliage height density in only one of four sampled stands of sand pine. This site was located in the peninsula where the influence of light was confounded by a recent stand-clearing fire. Moreover, we propose that stand-clearing fires in the peninsula may provide nutrient pulses and explain why we detected higher growth rates of sand pine in the peninsula than in the panhandle.

Thus, fire regimes may account for different size and age distributions and stand dynamics between panhandle and peninsula populations of sand pine. Although effects of hurricanes are apparent in panhandle populations as suggested by Parker et al. (2001a), panhandle populations would be expected to be uneven aged and sized even if hurricanes did not 
Table 5 Number of hurricanes (winds $>112 \mathrm{~km} / \mathrm{h}$ ) and number of 10-min intervals with winds $>112 \mathrm{~km} / \mathrm{h}$ from 1886 through 1994 for 12 study sites in the Florida panhandle and peninsula

\begin{tabular}{lll}
\hline Site & Hurricanes & $\begin{array}{l}\text { 10-min periods } \\
\text { with winds } \\
>112 \mathrm{~km} / \mathrm{h}\end{array}$ \\
\hline Panhandle & & \\
$\quad$ Big Lagoon & 21 & 315 \\
Rocky Bayou & 14 & 168 \\
St. Andrew & 13 & 216 \\
St. Joseph & 13 & 198 \\
Bald Point & 10 & 142 \\
Peninsula & & \\
Gold Head Branch & 8 & 145 \\
Big Scrub & 17 & 256 \\
Rock Springs Run & 14 & 210 \\
Wekiwa Springs & 16 & 229 \\
Saddleblanket & 25 & 304 \\
Arbuckle Tract & 22 & 272 \\
Highlands Hammock & 22 & 295 \\
\hline
\end{tabular}

occur (see Batista et al. 1998, Harcombe et al. 2002). Only differences in fire regimes are likely essential to producing differences in the structure of peninsula and panhandle stands.

We acknowledge that the structure and dynamics of plant populations can be affected by interacting multiple disturbance regimes, even in our study system (see Platt et al. 2002). When the effects of an additional disturbance are minimal (e.g., if the disturbance does not modify vegetation structure necessary for seedling establishment or significantly alter the demography of established individuals, as with present-day peninsula sand pine populations), no interaction will be evident. However, this scenario may change as the intensity of hurricanes increases. Large, Saffir-Simpson category hurricanes have historically crossed Gulf coastal sites every few hundred years (Liu and Fearn 2000). Such hurricanes may have intermittently increased the likelihood of highintensity fires, burning into low productivity xeric panhandle sand pine stands as a result of increased post-hurricane fuels (Myers and Van Lear 1998). Alternatively, current fire suppression patterns in the peninsula could enable recent hurricanes to generate effects that shift characteristics of peninsula stands toward those of panhandle stands, provided that cones open in the absence of fire.

Acknowledgments We thank all the people who helped us sample stands in the Florida panhandle and peninsula, especially Lance Gorham. Assistance in locating and permission to sample sand pine stands was provided by the Florida Department of Environmental Protection (Florida State Parks), US Forest Service (Ocala National Forest), The Nature Conservancy (Florida Chapter), and Florida Department of Agriculture, Division of Forestry (Lake Wales Ridge State Forest). Final revisions to the manuscript were guided by Jeffrey Chambers and two anonymous reviewers. This study was supported by a U.S. Fish and Wildlife Service Grant (W. J. Platt, PI)

\section{References}

Abrahamson WG (1984) Species responses to fire on the Florida Lake Wales Ridge. Am J Bot 71:35-43

Abrahamson WG, Johnson AF, Layne JN, Peroni PA (1984) Vegetation of the Archbold Biological Station, Florida: an example of the southern Lake Wales Ridge. Quart J Florida Acad Sci 47:209-250

Batista WB, Platt WJ, Macchiavelli RE (1998) Demography of a shade-tolerant tree (Fagus grandifolia) in a hurricanedisturbed forest. Ecology 79:38-53

Brown N, Jennings S, Clements T (2003) The ecology, silviculture and biogeography of mahogany (Swietenia macrophylla): a critical review of the evidence. Perspect Plant Ecol, Evol Syst 6:37-49

Buckley A, Hendrickson TO (1988) The distribution of Cladonia perforata Evans on the southern Lake Wales Ridge in Highlands County, Florida. Bryologist 91:354-356

Christman SP, Judd WS (1990) Notes on plants endemic to Florida scrub. Florida Scientist 53:52-73

Clewell AF (1985) Guide to the vascular plants of the Florida panhandle. Florida State University Press, Tallahassee, Florida

Conway DW, Parker AJ, Parker KC (1997) Understory light regime, shrub layer, and sand pine (Pinus clausa) regeneration in four scrub stands. Am Midl Nat 138:84-96

Cooper RW (1959) Sand pine regeneration on the Ocala National Forest. USDA Forest Service, Washington DC, Production Research Report No. 30

Díaz S, Mercado C, Alvarez-Cardenas S (2000) Structure and population dynamics of Pinus lagunae M.-F. Passini. Forest Ecol Manage 134:249-256

Doyle TW, Michot TC, Roetker F, Sullivan J, Melder M, Handley B, Balmat J (2002) Hurricane Mitch: landscape analysis of damaged forest resources of the Bay Islands and Caribbean coast of Honduras. US Department of the Interior, US Geological Survey Open File Report 03-175. Lafayette, Louisiana

Duchesne L, Ouimet R, Moore JD, Paquin R (2005) Changes in structure and composition of maple-beech stands following sugar maple decline in Quebec, Canada. Forest Ecol Manage 208:223-236 
Evans JK, Parker AJ, Parker KC, Leigh DS (1996) Edaphic properties and foliar elemental concentrations from sand pine (Pinus clausa) populations throughout Florida. Phys Geogr 17:219-241

Gilliam FS, Platt WJ (1999) Effects of long-term fire exclusion on tree species composition and stand structure in an oldgrowth Pinus palustris (Longleaf pine) forest. Plant Ecol 140:15-26

Gilliam FS, Platt WJ, Peet RK (2006) Natural disturbances and physiognomy of pine savannas: a phenomenological model. Appl Veg Sci 9:83-96

Godfrey RK (1988) Trees, shrubs, and woody vines of Northern Florida and adjacent Georgia and Alabama. The University of Georgia Press, Athens, Georgia

Goff FG, West D (1975) Canopy-understory interaction effects on forest population structure. Forest Sci 21:98-108

Greenberg CH (2003) Vegetation recovery and stand structure following a prescribed stand-replacement burn in sand pine scrub. Nat Areas J 23:141-151

Harcombe PA, Bill CJ, Fulton M, Glitzenstein JS, Marks PL, Elsik IS (2002) Stand dynamics over 18 years in a southern mixed hardwood forest, Texas, USA. J Ecol 90:947-957

Huffman JM, Platt WJ, Grissino-Mayer H, Boyce CJ (2004) Fire history of a barrier island slash pine (Pinus elliottii) savanna. Nat Areas J 24:258-268

Ida H (2000) Treefall gap disturbance in an old-growth beech forest in southwestern Japan by a catastrophic typhoon. J Veg Sci 11:825-832

Kalisz PJ, Stone EL (1984) The longleaf pine islands of the Ocala National Forest, Florida - a soil study. Ecology 65:1743-1754

Killeen TJ, Jardim A, Mamani F, Rojas N (1998) Diversity, composition and structure of a tropical semideciduous forest in the Chiquitania region of Santa Cruz, Bolivia. J Trop Ecol 14:803-827

Kneeshaw DD, Burton PJ (1997) Canopy and age structures of some old sub-boreal Picea stands in British Columbia. J Veg Sci 8:615-626

Laessle AM (1942) The plant communities of the Welaka area. Biological science series, vol IV, no. 1. University of Florida Press, Gainesville, pp 1-143

Laessle AM (1958) The origin and successional relationship of sandhill vegetation and sand-pine scrub. Ecol Monogr 28:361-387

Little EL Jr, Dorman KW (1952) Geographic differences in cone-opening in sand pine. J Forestry 50:204-205

Liu K, Fearn ML (2000) Reconstruction of prehistoric landfall frequencies of catastrophic hurricanes in north-western Florida from lake sediment records. Quaternary Res 54:238-245

McLaren KP, McDonald MA, Hall JB, Healey JR (2005) Predicting species response to disturbance from size class distributions of adults and saplings in a Jamaican tropical dry forest. Plant Ecol 181:69-84

Muller RN (1982) Vegetation patterns in the mixed mesophytic forest of eastern Kentucky. Ecology 63:1901-1917

Mulvania M (1931) Ecological survey of a Florida scrub. Ecology 12:528-540
Myers RK, Van Lear DH (1998) Hurricane-fire interactions in coastal forests of the south: a review and hypothesis. Forest Ecol Manage 103:265-276

Myers RL (1990) Scrub and high pine. In: Myers RL, Ewel JJ (eds) Ecosystems of Florida. University of Central Florida Press, Orlando, Florida, USA, pp 150-193

Outcalt KW (1997) An old-growth definition for sand pine forests. USDA Forest Service General Technical Report SRS-12. Southern Research Station, Asheville, North Carolina, USA

Parker AJ, Parker KC, McCay DH (2001a) Disturbance-mediated variation in stand structure between varieties of $P i$ nus clausa (sand pine). Ann Assoc Am Geogr 91:28-47

Parker AJ, Parker KC, Faust TD, Fuller MM (2001b) The effect of climatic variability on radial growth of two varieties of sand pine (Pinus clausa) in Florida, USA. Ann Forest Sci 58:333-350

Parker KC, Hamrick JL (1996) Genetic variation in sand pine (Pinus clausa). Can J Forest Res 26:244-254

Platt WJ (1999) Southeastern pine savannas. In: Anderson RC, Fralish JS, Baskin J (eds) The Savanna, Barren, and Rock outcrop communities of North America. Cambridge University Press, Cambridge, UK. pp 23-51

Platt WJ, Rathbun SL (1993) Dynamics of an old-growth longleaf pine population. Proc Tall Timbers Fire Ecol Conf 18:275-297

Platt WJ, Doren RF, Armentano TV (2000) Effects of Hurricane Andrew on stands of slash pine (Pinus elliottii var. densa) in the everglades region of south Florida (USA). Plant Ecol 146:43-60

Platt WJ, Beckage B, Doren RF, Slater HH (2002) Interactions of large-scale disturbances: prior fire regimes and hurricane mortality of savanna pines. Ecology 83:1566-1572

Poulson TL, Platt WJ (1996) Replacement patterns of beech and sugar maple in Warren Woods, Michigan. Ecology 77:1234-1253

Quigley MF, Platt WJ (1996) Structure and pattern in temperate seasonal forests. Vegetatio 123:117-138

Rubin BD, Manion PD, Faber-Langendoen D (2006) Diameter distributions and structural sustainability in forests. Forest Ecol Manage 222:427-438

Ryniker KA, Bush JK, Van Auken OW (2006) Structure of Quercus gambelii communities in the Lincoln National forest, New Mexico, USA. Forest Ecol Manage 233:69-77

SAS Institute Inc. (2001) SAS/STAT user's guide, version 9.1. SAS Institute, Cary, North Carolina

Schmelz DV, Lindsey AA (1965) Size-class structure of oldgrowth forests in Indiana. Forest Sci 11:258-264

Slater HH, Platt WJ, Baker DB, Johnson HA (1995) Effects of Hurricane Andrew on damage and mortality of trees in subtropical hardwood hammocks of Long Pine Key. Everglades National Park, Florida, USA

Sokal RR, Rohlf FJ (1995) Biometry, 3rd edn. WH Freeman and Company, New York

Taylor AH, Halpern CB (1991) The structure and dynamics of Abies magnifica forests in the southern Cascade Range, USA. J Veg Sci 2:189-200

Wang T, Liang Y, Ren HB, Yu D, Ni J, Ma KP (2004) Age structure of Picea schrenkiana forest along an altitudinal 
gradient in the central Tianshan Mountains, northwestern China. Forest Ecol Manage 196:267-274

Ward DB (1963) Contributions to the flora of Florida-2, Pinus (Pinaceae). Castanea 28:1-10
Westphal C, Tremer N, von Oheimb G, Hansen J, von Gadow $\mathrm{K}$, Hardtle W (2006) Is the reverse J-shaped diameter distribution universally applicable in European virgin beech forests? Forest Ecol Manage 223:75-83 